\section{Behavior of pubescent oak (Quercus pube- scens Willd.) wood to different thermal treatments}

\author{
Luigi Todaro $^{(1)}$, Angelo Rita ${ }^{(1)}$, Francesco Negro ${ }^{(2)}$, Nicola Moretti ${ }^{(1)}$, \\ Antonio Saracino ${ }^{(3)}$, Roberto Zanuttini ${ }^{(2)}$
}

Quercus pubescens Willd. is a common oak species in the Mediterranean area, where it is currently exploited mainly for purposes such as firewood. To improve the technological properties of its wood, various steaming and/or heat treatments were applied to 160 wood samples from a southern Italian stand, cut from either sapwood or heartwood, while 20 samples served as controls. Steaming was carried out in an autoclave at $120^{\circ} \mathrm{C}$, whereas heat treatments were performed in an oven at 150 or $200{ }^{\circ} \mathrm{C}$ for 3 or $6 \mathrm{~h}$. The equilibrium moisture content, swelling, mass loss, wood density, compression strength, color variation, and lignin content of the samples were measured and compared among treatments. The swelling and water adsorption of wood samples decreased due to the hydrothermal treatments. The mass loss was strictly related to the temperature and duration of the heat treatments, whereas it was not influenced by the steaming treatment. The average axial compression strength value was positively influenced by the combination of steaming and heat treatments. A significant and general darkening of color was also observed for the harshest treatments, while an increase of lignin content was detected mainly in the sapwood. Thus, pubescent oak wood subjected to steaming and heat treatments may acquire useful characteristics suitable for its industrial use.

Keywords: Steaming, Moisture Content, Swelling, Color, Strength, Ray Cells

\section{Introduction}

Pubescent or Downy oak (Quercus pubescens Willd.) is a deciduous species characterized by high morphological variability (Schwarz 1993) and a widespread distribution range, from western to eastern Europe (Jalas \& Suominen 1976). Pubescent oak covers with monospecific stands 876000 and 850000 ha in France and Italy, respectively (IGN 2013, INFC 2007). In other Mediterranean countries, e.g., Slovenia, Croatia, Montenegro, and Albania, the growing stock of mixed or pure stands of this species is rather limited, according to the national forest inventories. In general, the wood of pubescent oak is scarcely considered as industrial lumber and is mainly used as firewood. In the past, it was largely employed for rail crossbeams, while nowadays it is occasionally used for carpentry, boat-building, or packaging. It is well known that through adequate modification processes, its wood properties may be improved, creating a new and environmental-friendly material (Hill 2006).

Thermal treatment of wood is applied since the beginning of the last century, when several studies demonstrated the reduced equilibrium moisture content and consequently reduced dimensional shrinkage of wood exposed to a high temperature (Kollman 1936, Stamm et al. 1946, Kollman \& Schneider 1963). Lately, a great interest in thermal processing of wood had been rising, and several

(1) School of Agricoltural, Forest, Food and Environmental Science, University of Basilicata, Potenza (Italy); (2) Department of Agricultural, Forest and Food Sciences, University of Torino (Italy); (3) Department of Agriculture, Division of Biology and Protection of Agricultural and Forest Systems (BIPAF), University of Naples "Federico II" (Italy)

@ Antonio Saracino (a.saracino@unina.it)

Received: May 12, 2014 - Accepted: Oct 01, 2014

Citation: Todaro L, Rita A, Negro F, Moretti N, Saracino A, Zanuttini R, 2015. Behavior of pubescent oak (Quercus pubescens Willd.) wood to different thermal treatments. iForest 8: 748-755 [online 2015-02-16] URL: http://www.sisef.it/iforest/contents/?id=ifor1348-007

Communicated by: Giacomo Goli

types of thermal treatments have been developed. Most studies aimed at analyzing the variation in the different treatment phases of several wood parameters, such as moisture content, dimensional stability, durability, mass loss, color changes, mechanical properties, and chemical modifications (Esteves \& Pereira 2009).

Nowadays, the industrial and scientific interest in thermally treated wood is undergoing a "new age", promoted by the growing demand for environmental-friendly construction products. Although the scientific literature is rich of studies describing the improved technological properties of several species, scant information is available on the wood of pubescent oak. In general, based on its wood properties, the choice of the most suitable thermal treatment for pubescent oak is often troublesome.

Pubescent oak wood veining is macroscopically indistinguishable from other oak species. In fact, there are no significant differences in its strength properties as compared with other deciduous oak species, though pubescent oak wood is heavier with a large shrinkage, and consequently very prone to cracking (Giordano 1981). In addition, the presence of reaction wood, as well as cross grain or internal tensions, can cause serious warping, such as bowing, crooking, or twisting, and cross breaks develop in the areas of major shrinkage (Giordano 1994). Also, pubescent oak wood shows remarkable chromatic differences between sapwood and heartwood, being the latter usually darker. Furthermore, its high level of extractives, along with other features such as tylosis, make this wood less permeable and more difficult to be treated with chemical additives (Hillis 1987, Bamber \& Fukazawa 1985). Presently, not enough information is available for a suitable industrial exploitation of pubescent oak wood.

The starting hypothesis of this study was that the factors limiting the utilization of pubescent oak wood could be reduced by applying appropriate hydrothermal treatments. In particular, a reduction in the equilibrium moisture content and consequently an improvement in the dimensional stability could be possibly achieved. Therefore, the main objective of this work was to determine the influence of thermal and combined (steam and heat) treatments on some basic properties of pubescent oak wood, such as dimensional variations, equilibrium moisture content, mass loss, compression strength, lignin content, and color variation.

\section{Material and methods}

Four pubescent oak trees were sampled from a mixed Quercus spp. forest located in the Basilicata region (southern Italy). Some $30 \mathrm{~mm}$-thick boards were sawed in parallel 
Tab. 1 - Treatment schedules and number of samples (n) analyzed. (ST): steaming.

\begin{tabular}{clcccccc}
\hline Group & $\begin{array}{l}\text { Treatment } \\
\left({ }^{\circ} \mathbf{C}, \mathbf{h}\right)\end{array}$ & $\begin{array}{c}\text { Steaming } \\
\left({ }^{\circ} \mathbf{C}\right)\end{array}$ & $\begin{array}{c}\text { Heating } \\
\left({ }^{\circ} \mathbf{C}\right)\end{array}$ & $\begin{array}{c}\text { Time } \\
(\mathbf{h})\end{array}$ & $\begin{array}{c}\text { Heartwood } \\
(\mathbf{n})\end{array}$ & $\begin{array}{c}\text { Sapwood } \\
(\mathbf{n})\end{array}$ & $\begin{array}{c}\text { Total } \\
(\mathbf{n})\end{array}$ \\
\hline 1 & Control & - & - & - & 10 & 10 & 20 \\
\hline 2 & $150 \times 3 \mathrm{~h}$ & - & 150 & 3 & 10 & 10 & 20 \\
3 & $150 \times 6 \mathrm{~h}$ & - & 150 & 6 & 10 & 10 & 20 \\
4 & $200 \times 3 \mathrm{~h}$ & - & 200 & 3 & 10 & 10 & 20 \\
5 & $200 \times 6 \mathrm{~h}$ & - & 200 & 6 & 10 & 10 & 20 \\
\hline 6 & $\mathrm{ST}+150 \times 3 \mathrm{~h}$ & 120 & 150 & 3 & 10 & 10 & 20 \\
7 & $\mathrm{ST}+150 \times 6 \mathrm{~h}$ & 120 & 150 & 6 & 10 & 10 & 20 \\
8 & $\mathrm{ST}+200 \times 3 \mathrm{~h}$ & 120 & 200 & 3 & 10 & 10 & 20 \\
9 & $\mathrm{ST}+200 \times 6 \mathrm{~h}$ & 120 & 200 & 6 & 10 & 10 & 20 \\
\hline
\end{tabular}

from each log. From each board, samples without defects with dimensions of $20 \mathrm{~mm}$ (tang) $\times 20 \mathrm{~mm}(\mathrm{rad}) \times 40 \mathrm{~mm}$ (long) were randomly selected and cut. Overall, 180 wood samples were obtained, none of which included the pith section.

Samples were then assigned to nine different treatment groups, equally distributed between heartwood and sapwood. The description of treatments for each group is reported in Tab. 1. The control group (Group 1) was not subjected to any treatment. Groups $2-5$ were subjected to a thermal treatment, while groups 6-9 received a combination of steaming and heat treatment. Each group was subjected to a specific treatment in terms of steaming, heating, and time (Tab. 1).

Prior to any treatment, all samples were conditioned at $20 \pm 2{ }^{\circ} \mathrm{C}$ and $65 \%$ relative humidity until a constant mass was reached, and then dried in an oven at $103{ }^{\circ} \mathrm{C}$ for $24 \mathrm{~h}$, in order to balance the moisture content. The mass, dimensions, and color coordinates of each specimen were measured before and after treatment.

\section{Steaming}

Eighty samples were subjected to an indirect steaming inside an autoclave with a maximum capacity of $23 \mathrm{~L}$ (Vapormatic 770/A, Asal s.r.l., Cernusco, Italy). The cy-

cle was completely automatic, thermoregulated, and controlled by an HMOS microprocessor that enables programming different times and temperatures (from 100 to 130 $\left.{ }^{\circ} \mathrm{C}\right)$. The performed steaming cycles are displayed in Fig. 1. The main goal of the steaming phase was to slow the release of internal tensions, and consequently to reduce the formation of surface checks and sharpness, which are particularly present in pubescent oak wood. Afterward, the dimensions, mass, and color coordinates were also determined.

\section{Heating}

The samples were treated in a small heating unit with $\pm 1{ }^{\circ} \mathrm{C}$ accuracy under atmospheric pressure, according to two different heating cycles (see Tab. 1). In order to reduce the formation of surface checks during the thermal treatment, a bowl containing $1 \mathrm{~L}$ of distilled water was placed in the oven at the beginning of each cycle. The samples were then weighed, and their tangential, radial, and axial dimensions measured before and after each treatment.

\section{Characterization tests}

After treatment, the samples were reconditioned in a climatic chamber at $20 \pm 2{ }^{\circ} \mathrm{C}$ and $65 \%$ relative humidity. The differences in weight due to moisture content adsorption

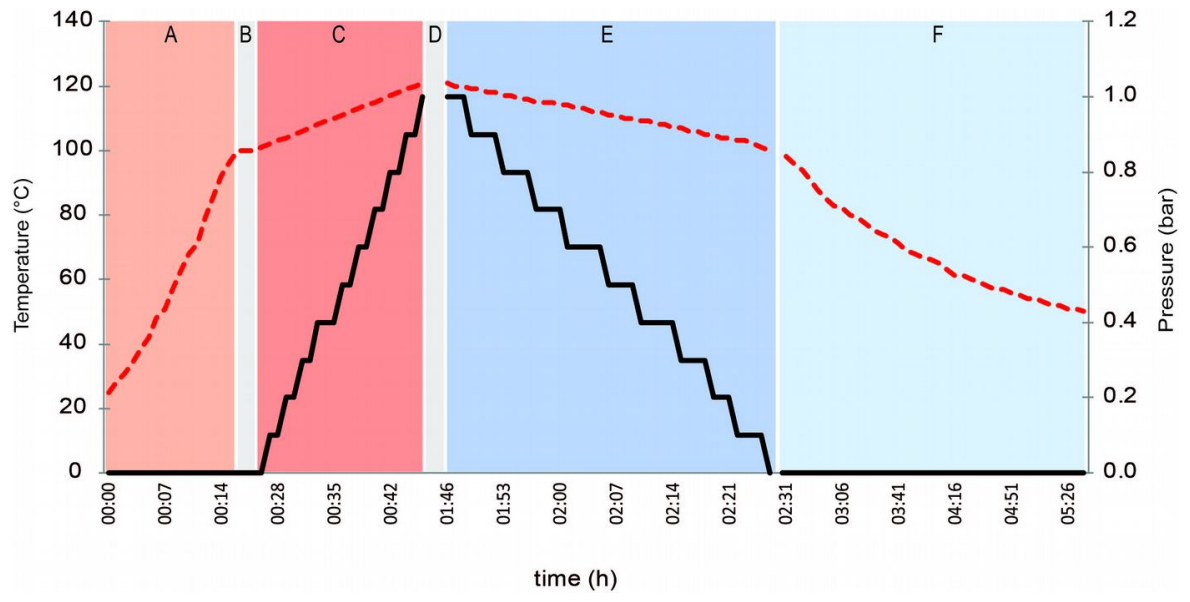

Fig. 1 - Steaming cycle. The red dashed line represents the temperature $\left({ }^{\circ} \mathrm{C}\right)$, and the black line represents the pressure (bar). were measured daily during the first week, and weekly thereafter.

The equilibrium moisture content and radial-tangential-total swelling were measured on strictly radial-tangential-oriented samples with dimension of $20 \times 20 \times 40 \mathrm{~mm}$ according to UNI-ISO-3130 (1975), UNI-ISO4859 (1988) and UNI-ISO-4860 (1988) standards. The swelling was determined as follows (exemplified for tangential, $t g$ - eqn. 1):

$$
\beta_{l(\%)}=\frac{\operatorname{Ltg}_{\text {moist }}-\operatorname{Ltg}_{\text {ovendry }}}{\operatorname{Ltg}_{\text {ovendry }}} \cdot 100
$$

The mass loss was determined by weighing the boards of the stack prior to the thermal treatment (at a moisture content of $0 \%$ ) and immediately after, and it was expressed as percentage. The wood density $\left(\mathrm{kg} \mathrm{m}^{-3}\right)$ was determined according to the UNI-ISO-3131 standard and was expressed as mass per volume, where mass (in g) was calculated by an electronic scale with an accuracy of \pm 0.001 $\mathrm{g}$; and the volume $\left(V\right.$, in $\left.\mathrm{cm}^{3}\right)$ was calculated by measuring the three dimensions with a caliper having an accuracy of $\pm 0.001 \mathrm{~cm}^{3}$. The Klason lignin content was assessed by a modified TAPPI (1954) method, resulting from the attack of sulfuric acid on the extractive-free material and quantifying the lining as a precipitate. To determine the compression strength parallel to the grain, the samples were tested according to UNI-ISO-3787 after 4 weeks in a climatic chamber (see Tab. 2 for the average moisture content values). According to the CIELAB system, color parameters were used to verify the color modifications. $L^{*}, a^{*}$, and $b^{*}$ were measured on each specimen on the radial and tangential sections of untreated and treated wood, and their average values were calculated for each treatment. Measures were taken using a Minolta CM-2002 spectrophotometer (Minolta Corp., Osaka, Japan) with a pulsed Xenon arc light source on measurement areas of 8 $\mathrm{mm}$ in diameter. Color variations (exemplified below for $L^{*}$ ) were determined according to the following formula (eqn. 2):

$$
\Delta L^{*}=L_{\text {treated }}^{*}-L_{\text {initial }}^{*}
$$

The color changes of $\Delta L^{*}, \Delta a^{*}$, and $\Delta b^{*}$ of each sample before and after treatments were also used to calculate the total color change $(\triangle E)$ according to the following formula (eqn. 3):

$$
\Delta E=\sqrt{\Delta L^{* 2}+\Delta a^{* 2}+\Delta b^{* 2}}
$$

The difference after treatments between heartwood and sapwood was determined as follows (exemplified below for $L^{*}$ - eqn. 4):

$$
L^{*}=\frac{L_{\text {heartwood }}^{*}-L_{\text {sapwood }}^{*}}{L_{\text {sapwood }}^{*}} \cdot 100
$$

Analysis of variance was performed by ap- 
plying the general factor model procedure implemented in the software package SPSS ver. 10.0. Post-hoc Duncan's multiple range test $(\alpha=0.05)$ was used to test for differences among means of each measured parameter in relation to the treatment applied.

\section{Results and discussion}

\section{Moisture content variation}

The moisture adsorption was mainly related to the temperature used in the process (Fig. 2 and Tab. 2). After 4 weeks in the climatic chamber, moisture content of the control samples was $7.6 \%$, which was not statistically different from treatments 2,3 , or 7 . In contrast, the reduction in water adsorption was statistically significant when the wood was heated at $200{ }^{\circ} \mathrm{C}$ (Tab. 2).

Treatments 5 and 9 , which were subjected to higher temperature for a longer duration, resulted in a low water adsorption after 4 weeks in a climatic chamber $(5.8 \%$ and $5.7 \%$, respectively). In contrast, the samples heated at $150{ }^{\circ} \mathrm{C}$ for $3 \mathrm{~h}$ and steamed showed a low reduction $(7.2 \%)$ of water adsorption, as compared with the controls after 4 weeks. These results indicated that a higher temperature is required to obtain a significant improvement in the moisture content. Furthermore, similar results were obtained using the same temperature during the heating cycle, regardless of whether steaming treatment was applied. Nevertheless, the heating duration significantly affected the moisture content (treatments 4, 5, 8, and 9).

Sundqvist (2004) reported that noticeable changes in the lignin structure occur at a temperature of approximately $120{ }^{\circ} \mathrm{C}$. For wet conditioned wood, lignin can plasticize and change in structure even at $100{ }^{\circ} \mathrm{C}$. However, the samples in our study were not steamed under wet conditions. On the contrary, we previously reported about significant variations in moisture content at $120^{\circ} \mathrm{C}$ both for steaming and heating when wet wood was used (Todaro et al. 2012b). These facts confirmed the hypothesis that the steaming process assumes a greater importance under wet conditions as compared with dry conditions. Thus, in our study, the positive effect of steaming on moisture content reduction was weakly depicted (Tab. 2), compared with other similar studies (Todaro et al. 2012a, 2012b).

\section{Sapwood and heartwood}

We found that sapwood of pubescent oak adsorbed water more easily than heartwood when exposed to severe treatments $\left(200{ }^{\circ} \mathrm{C}\right.$ Fig. 3). After the adsorption phase, the relative difference of moisture content between sapwood and heartwood increased with temperature and duration, both in the steamed and not steamed samples. In fact, hygroscopic inertia seemed to increase, except for
Tab. 2 - Equilibrium moisture content (ECM, \%) at 4 weeks after treatment. Values in parentheses are standard deviations. Different letters indicate significant differences between means after Duncan's multiple range test $(\mathrm{p}<0.05)$. (ST): steaming.

\begin{tabular}{clcc}
\hline Group & Treatment $\left({ }^{\circ} \mathbf{C}, \mathbf{h}\right)$ & EMC at the $\mathbf{4}^{\text {th }}$ week $(\%)$ & Decrease (\%) \\
\hline 1 & Control & $7.6(0.4)^{\mathrm{d}, \mathrm{e}}$ & - \\
2 & $150 \times 3 \mathrm{~h}$ & $7.8(0.3)^{\mathrm{e}}$ & 1.8 \\
3 & $150 \times 6 \mathrm{~h}$ & $7.7(0.4)^{\mathrm{d}, \mathrm{e}}$ & 0.2 \\
4 & $200 \times 3 \mathrm{~h}$ & $6.2(0.4)^{\mathrm{b}}$ & -19.2 \\
5 & $200 \times 6 \mathrm{~h}$ & $5.8(0.4)^{\mathrm{a}}$ & -23.8 \\
6 & $\mathrm{ST}+150 \times 3 \mathrm{~h}$ & $7.2(0.4)^{\mathrm{c}}$ & -6.0 \\
7 & $\mathrm{ST}+150 \times 6 \mathrm{~h}$ & $7.5(0.3)^{\mathrm{d}}$ & -2.2 \\
8 & $\mathrm{ST}+200 \times 3 \mathrm{~h}$ & $6.2(0.3)^{\mathrm{b}}$ & -18.5 \\
9 & $\mathrm{ST}+200 \times 6 \mathrm{~h}$ & $5.7(0.3)^{\mathrm{a}}$ & -25.9 \\
\hline
\end{tabular}

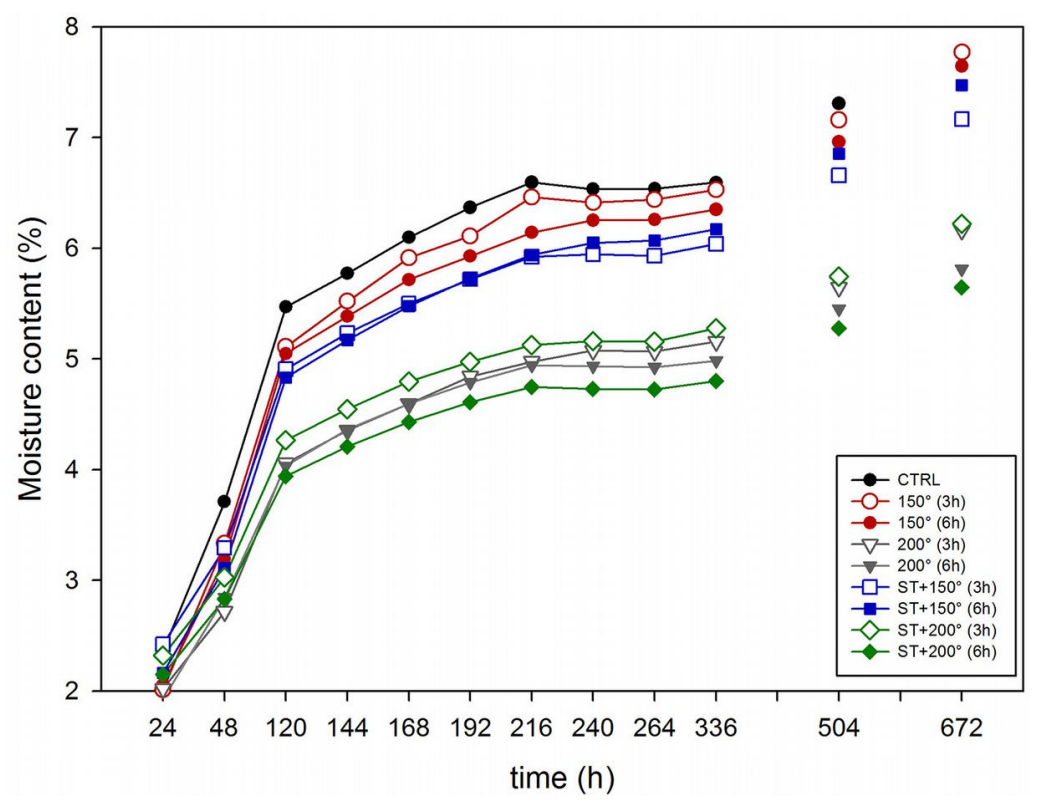

Fig. 2 - Variation in time of moisture content according to the different treatments applied.

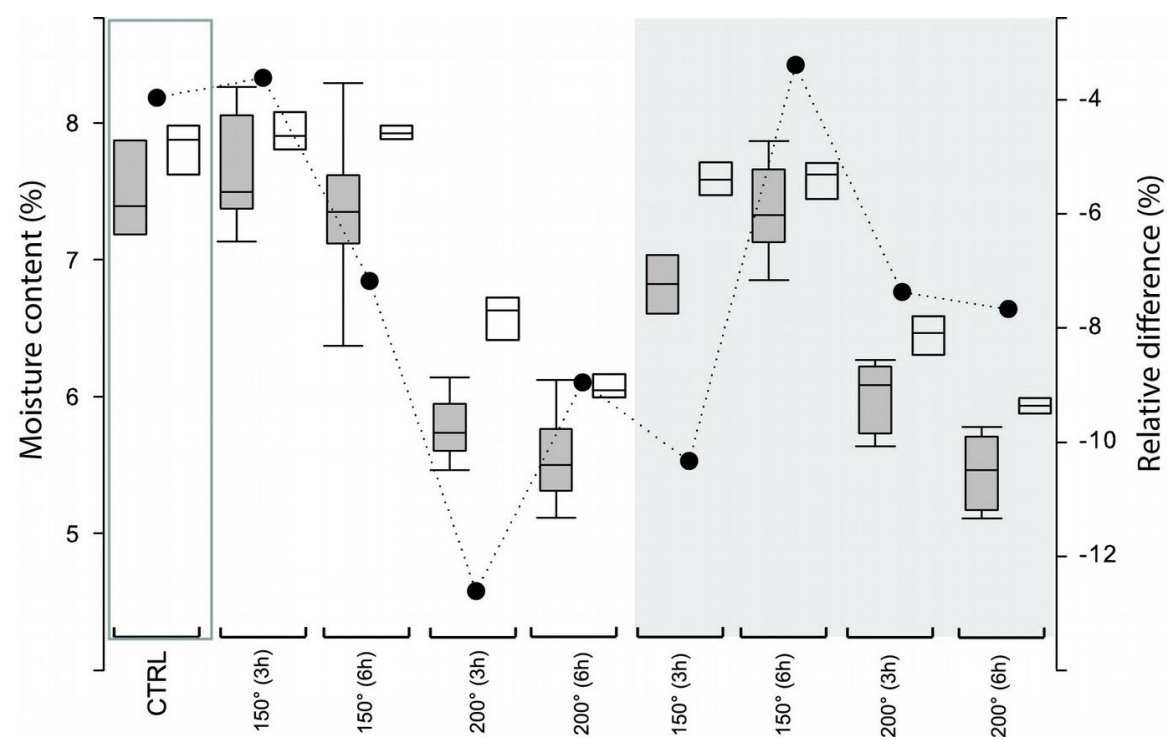

Fig. 3 - Moisture content in sapwood and heartwood after 4 weeks in the climatic chamber. Gray and white boxes are heartwood and sapwood, respectively. The dotted line represents the relative difference (\%) between sapwood and heartwood. The shaded area refers to samples submitted to the steaming treatment. 


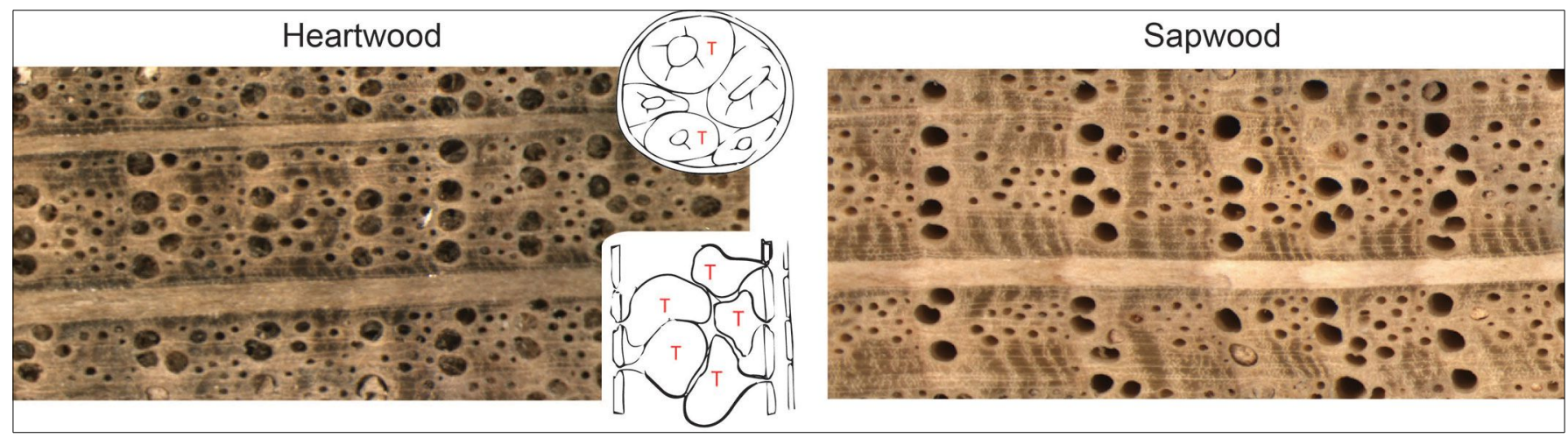

Fig. 4 - Tylosis (T) and color differences between the heartwood (left) and the sapwood (right) of pubescent oak.

treatments 2 and 7 , in which the differences between sapwood and heartwood moisture content were similar to those of the control.

Considering the general and significant reduction of moisture content previously observed (except for treatments 2, 3, and 7 Tab. 2), a higher increase in water adsorption was detected in sapwood than in heartwood. Treatment with both heat and steam seemed to increase the hygroscopic inertia during the adsorption process, mainly in the heartwood where the presence of tylosis (Fig. 4) may decrease the permeability (Dashti et al. 2012). Tylosis is the result of enzymatic hydrolysis breaking down the pit membrane between a parenchyma cell and an adjacent vessel. This process allows a portion of the parenchmya protoplast to extrude into the vessel lumen (Taylor et al. 2002). Sohar et al. (2012) have reported that in oak species, sapwood is distinguished from heartwood by its lighter color and the absence of tylosis in earlywood vessels. Thus, the degree of tylosis in the Quercus spp. (Hillis 1987, Pallardy 2008) may affect the fluid flow, which limits the moisture uptake, hampers the physical movement of pathogens through the wood, and increases its durability (Taylor et al. 2002). Moreover, in the treatment at $200{ }^{\circ} \mathrm{C}$ with steaming, groups 8 and 9 showed a reduced moisture content difference between sapwood and

Tab. 3 - Tangential and radial swelling after 4 weeks in a climatic chamber at $20{ }^{\circ} \mathrm{C}$ and $65 \%$ relative humidity. Values in parentheses are standard deviations. Different letters indicate significant differences between means after Duncan's multiple range test $(\mathrm{p}<0.05)$. (ST): steaming.

\begin{tabular}{clcccc}
\hline Group & $\begin{array}{l}\text { Treatment } \\
\left({ }^{\circ} \mathbf{C}, \mathbf{h}\right)\end{array}$ & $\begin{array}{c}\text { Tangential } \\
\text { Swelling (\%) }\end{array}$ & $\begin{array}{c}\text { Decrease } \\
(\%)\end{array}$ & $\begin{array}{c}\text { Radial } \\
\text { swelling (\%) }\end{array}$ & $\begin{array}{c}\text { Decrease } \\
(\%)\end{array}$ \\
\hline 1 & Control & $2.1(0.6)^{\mathrm{c}}$ & - & $1.4(0.4)^{\mathrm{d}}$ & - \\
2 & $150 \times 3 \mathrm{~h}$ & $1.9(0.5)^{\mathrm{c}}$ & -12.8 & $1.3(0.3)^{\mathrm{b}, \mathrm{c}}$ & -6.3 \\
3 & $150 \times 6 \mathrm{~h}$ & $1.9(0.3)^{\mathrm{c}}$ & -8.3 & $1.2(0.3)^{\mathrm{b}, \mathrm{c}}$ & -11.1 \\
4 & $200 \times 3 \mathrm{~h}$ & $1.5(0.2)^{\mathrm{a}}$ & -31.0 & $1.2(0.4)^{\mathrm{b}}$ & -14.8 \\
5 & $200 \times 6 \mathrm{~h}$ & $1.4(0.5)^{\mathrm{a}}$ & -35.7 & $0.9(0.3)^{\mathrm{a}}$ & -31.4 \\
6 & $\mathrm{ST}+150 \times 3 \mathrm{~h}$ & $1.8(0.6)^{\mathrm{b}, \mathrm{c}}$ & -15.5 & $1.3(0.3)^{\mathrm{b}, \mathrm{c}}$ & -2.7 \\
7 & $\mathrm{ST}+150 \times 6 \mathrm{~h}$ & $1.9(0.6)^{\mathrm{c}}$ & -9.4 & $1.3(0.5)^{\mathrm{b}, \mathrm{c}}$ & -5.8 \\
8 & $\mathrm{ST}+200 \times 3 \mathrm{~h}$ & $1.4(0.4)^{\mathrm{a}}$ & -32.0 & $1.4(0.3)^{\mathrm{c}}$ & -1.3 \\
9 & $\mathrm{ST}+200 \times 6 \mathrm{~h}$ & $1.5(0.4)^{\mathrm{a}, \mathrm{b}}$ & -29.1 & $1.4(0.4)^{\mathrm{d}}$ & 5.0 \\
\hline
\end{tabular}

heartwood, compared to groups 4 and 5 . Therefore, the presence of tylosis is crucial to improve the characteristics of pubescent oak subjected to hydrothermal treatment.

\section{Swelling}

Wood swelling was measured after 4 weeks in a climatic chamber (Tab. 3 ). In the tangential direction, the groups heated at 200 ${ }^{\circ} \mathrm{C}$ (treatments 4, 5, 8, and 9) adsorbed a lower amount of water. The treated material also showed a high dimensional stability: this is fundamental considering that pubescent oak wood is particularly prone to volume and shape variations.

Contrasting results were found regarding data indicated that the influence of moisture adsorption on swelling was limited to the tangential direction of pubescent oak wood, at least in the treatment combining steaming and heating. In fact, in the radial direction, the treatment effect was remarkable only in samples not treated with steaming, likely because during steaming permanent changes occurred in samples due to swelling. This assumption is in accordance with Babicki et al. (1977), who found an increase of beech wood volume during the first period of hydrothermal treatment $(1-5 \mathrm{~h})$. On the other hand, Rybarczyk \& Ganowicz (1974) described detailed information regarding the swelwood swelling in the radial direction. Our ling pressure of wood, indicating permanent deformation in both the radial and tangential directions.

Differences in behavior between the radial and tangential directions are clearly related to the anisotropy of wood (Todaro 2012), with particular reference to the radial ray cells, which are large and abundant in pubescent oak, thus affecting the physical and mechanical properties of wood (Burgert et al. 2001). It has been hypothesized that during the absorption of water, the radial ray cells may act as a longitudinal barrier to the movement of wood (Todaro et al. 2012b). Reiterer et al. (2002) also confirmed that the volume fraction of ray cells affects wood mechanical properties in the radial direction, while has negligible effect in the tangential direction. This is likely a consequence of the contrasting anisotropy and geometry of the ray cells as compared with other wood tissue cells (Burgert et al. 2001).

\section{Mass loss and density variation}

Our analysis revealed that the oven-dry mass loss was not related to the steaming treatment, but it was only associated with the heat treatment temperature and its duration (Tab. 4). Such results indicated that the mass loss was significantly higher in material treated at $200{ }^{\circ} \mathrm{C}$ for $6 \mathrm{~h}$ with or without steaming, while heat treatment at $150{ }^{\circ} \mathrm{C}$ led to slight mass changes.

Modifications of hemicellulose, cellulose, and lignin occur at high temperatures, influencing the wood properties such as mass loss, hygroscopicity, mechanical resistance, swelling, natural durability, etc. Therefore, the extent of the above modifications depends mainly on the steaming and heating temperatures, as well as the treatment duration (Esteves \& Pereira 2009).

Concerning the wood density variation (Tab. 4), a significant difference only was observed in the samples that had first been subjected to steaming, suggesting that the application of this treatment may be useful for uniformly preparing the wood for further processing. In fact, hydrothermal treatment 
significantly influenced the density of samples previously steamed. Groups 6 to 9 all showed a lower wood density after the combination of steaming and heat treatment, as compared with both the control sample (group 1) and samples subjected to thermal treatment only (groups 2-5). These results paralleled those found by Kartal et al. (2001), in a study on beech wood submitted to steaming treatment. Assor et al. (2009) hypothesized that steaming may affect the degradation of wood components by promoting hydrolysis of some chemical compounds and a partial removal of extractives (Kartal et al. 2001), with a consequent effect on the wood density.

\section{Compression strength}

The compression strengths of the samples heated at $200{ }^{\circ} \mathrm{C}$ with no steaming were only slightly greater than those of the control: the mechanical resistance of group 4 increased by $7.4 \%$ and that of group 5 increased by $8.3 \%$. Meanwhile, no significant increases were observed in groups 2 and 3 (Fig. 5). In contrast, the compression strength parallel to the grain was clearly increased after steaming and heat treatment (Fig. 5) at both 150 and $200{ }^{\circ} \mathrm{C}$ (groups 6-9). Compared to the control, an increase of strength from 15.7\% (group 7) to $17.4 \%$ (group 9) was observed. Similar findings were reported by Boonstra et al. (2007), who ascribed such results to an increased cross-linking of the lignin polymer network, which improves the strength of the middle lamella, consequently affecting the strength properties of the cell wall parallel to the grain.

The lower moisture content (Tab. 2) is likely a key factor accounting for the observed improvement of some mechanical properties after the thermal treatment. However, higher temperatures and a longer process duration may enhance the risk of wood fiber modifications, making wood less resistant to compression (Esteves \& Pereira 2009, Mitchell 1988). Therefore, an appropriate balance among temperature, moisture content, pressure, and treatment duration must be maintained in order to improve wood properties.

\section{Color variation}

The color measurements of the wood samples showed a general darkening of the surface (Fig. 6). Darkening was more evident for the stronger treatments $\left(\mathrm{ST}+200{ }^{\circ} \mathrm{C} \times 3\right.$ $\mathrm{h}$ and $6 \mathrm{~h}$ ), while the weakest treatments $\left(150{ }^{\circ} \mathrm{C} \times 3 \mathrm{~h}\right)$ showed the lowest reduction $(-2.9)$. Little variation of the red index in relation to treatment was observed, whilst the strongest treatments produced significant variation of the yellow index. As reported by Terziev (1995), these results were probably due to the enrichment of sugar and nitrogenous compounds at the wood surface during treatment. In addition, statistical analysis
Tab. 4 - Mean density $\left(\mathrm{kg} \mathrm{m}^{-3}\right)$ at the origin (wet state), after treatments, and after 4 weeks in a climatic chamber. Oven dry mass loss (\%) and standard deviation (in parentheses) after thermal treatments. Different letters indicate significant differences between means after Duncan's multiple range test $(\mathrm{p}<0.05)$. (ST): steaming; $(\mathrm{ns})$ : not significant.

\begin{tabular}{clccccc}
\hline Group & $\begin{array}{l}\text { Treatment } \\
\left({ }^{\circ} \mathbf{C}, \mathbf{h}\right)\end{array}$ & $\begin{array}{c}\text { Origin } \\
\left(\mathbf{k g ~ m}^{-3}\right)\end{array}$ & $\begin{array}{c}\text { After } \\
\text { steaming } \\
\left(\mathbf{k g ~ m}^{-3}\right)\end{array}$ & $\begin{array}{c}\text { After heat } \\
\text { treatment } \\
\left(\mathbf{k g} / \mathbf{m}^{-3}\right)\end{array}$ & $\begin{array}{c}\text { Mass loss } \\
(\mathbf{\%})\end{array}$ & $\begin{array}{c}\mathbf{4}^{\text {th }} \text { week } \\
\left(\mathbf{k g ~ m}^{-3}\right)\end{array}$ \\
\hline 1 & Control & $857^{\mathrm{a}}$ & - & - & 0 & $842^{\mathrm{a}, \mathrm{b}, \mathrm{c}}$ \\
2 & $150 \times 3 \mathrm{~h}$ & $874^{\mathrm{a}, \mathrm{b}}$ & - & $826^{\mathrm{c}, \mathrm{d}}$ & $0.3(0.1)^{\mathrm{a}}$ & $863^{\mathrm{c}}$ \\
3 & $150 \times 6 \mathrm{~h}$ & $880^{\mathrm{a}, \mathrm{b}}$ & - & $830^{\mathrm{c}, \mathrm{d}}$ & $0.6(0.1)^{\mathrm{b}, \mathrm{c}}$ & $865^{\mathrm{c}}$ \\
4 & $200 \times 3 \mathrm{~h}$ & $903^{\mathrm{b}}$ & - & $846^{\mathrm{d}}$ & $2.5(0.3)^{\mathrm{g}}$ & $874^{\mathrm{c}}$ \\
5 & $200 \times 6 \mathrm{~h}$ & $881^{\mathrm{a}, \mathrm{b}}$ & - & $819^{\mathrm{b}, \mathrm{c}, \mathrm{d}}$ & $3.5(0.4)^{\mathrm{f}}$ & $846^{\mathrm{b}, \mathrm{c}}$ \\
6 & $\mathrm{ST}+150 \times 3 \mathrm{~h}$ & $871^{\mathrm{a}, \mathrm{b}}$ & $822^{\mathrm{ns}}$ & $783^{\mathrm{a}}$ & $0.4(0.1)^{\mathrm{a}, \mathrm{b}}$ & $814^{\mathrm{a}, \mathrm{b}}$ \\
7 & $\mathrm{ST}+150 \times 6 \mathrm{~h}$ & $871^{\mathrm{a}, \mathrm{b}}$ & $820^{\mathrm{ns}}$ & $780^{\mathrm{a}}$ & $0.6(0.2)^{\mathrm{c}}$ & $811^{\mathrm{a}}$ \\
8 & $\mathrm{ST}+200 \times 3 \mathrm{~h}$ & $880^{\mathrm{a}, \mathrm{b}}$ & $834^{\mathrm{ns}}$ & $786^{\mathrm{a}, \mathrm{b}}$ & $2.1(0.3)^{\mathrm{d}}$ & $810^{\mathrm{a}}$ \\
9 & $\mathrm{ST}+200 \times 6 \mathrm{~h}$ & $900^{\mathrm{b}}$ & $851^{\mathrm{ns}}$ & $805^{\mathrm{a}, \mathrm{b}, \mathrm{c}}$ & $3.7(0.4)^{\mathrm{f}}$ & $826^{\mathrm{a}, \mathrm{b}}$ \\
\hline
\end{tabular}

confirmed that hydrothermal treatments led to significant total color modifications $(\Delta E)$, with a great difference between treated and untreated wood when samples were submitted to the highest temperature. Indeed, our results indicate that temperature and (to a less extent) time of treatment significantly affected the color variation ( $\triangle E$ - Fig. 6$)$, as already reported by Tolvaj \& Molnar (2006). Changes in $\Delta E$ were mainly due to $L^{*}$ and less affected by $a^{*}$ and $b^{*}$.

Comparison between sapwood and heartwood submitted to the same treatment indicated that the hydrothermal treatment reduced color differences inside the wood (Tab. 5). According to Sundqvist \& Morén (2002), a prevalent role in wood color changes after hydrothermal treatments is played by extractives, which are more abundant in heartwood than in sapwood and are the first compounds degraded during that process. In addition, hydrolysis is an important reaction occurring when wood is heat-treated and moisture is present in wood cells or under steaming conditions. The temperature and duration of heat treatment during steaming has been found as the most important factor affecting darkening in hardwoods (Sundqvist 2004). Discoloration of oak also might occur at lower temperatures, though only when the wood is wet and the drying treatment is prolonged (Stamm 1956, Schmidt 1986).

\section{Lignin content}

The proportion of lignin content in the wood remained almost unchanged at $150{ }^{\circ} \mathrm{C}$, but increased in the samples heated at 200 ${ }^{\circ} \mathrm{C}$ (Tab. 6). However, such results should be considered with caution, as some of the thermally degraded carbohydrates may have been incorporated within the lignin during its determination (Tjeerdsma \& Militz 2005), leading to the overestimation of lignin content (Yildiz et al. 2006, Zaman et al. 2000). It is important to note that the lignin percentage observed in the heartwood remained almost unchanged or decreased, leading to the assumption that a fixed percentage of lignin remained (Yildiz et al. 2006). The underlying cause is unknown and deserves to be further investigated. In fact, the lignin content increased in the sapwood samples as com-

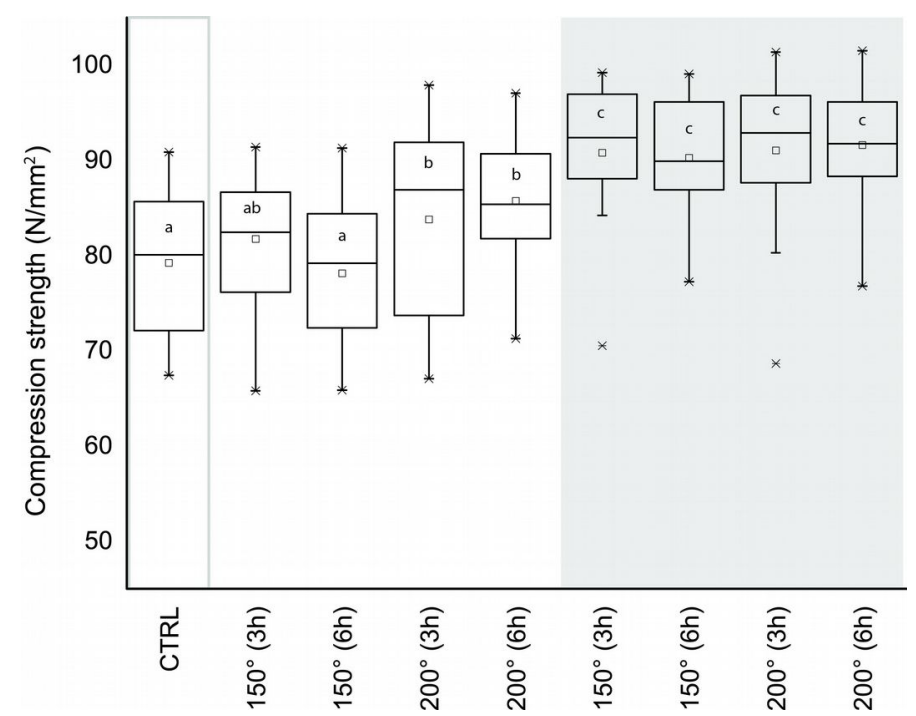

Fig. 5 - Compression strengths of samples with the moisture content as reported in Tab. 2. The shaded area refers to samples submitted to the steaming treatment. Different letters indicate significant differences between means after Duncan's multiple range test $(\mathrm{p}<0.05)$.

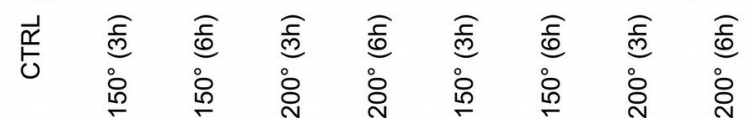




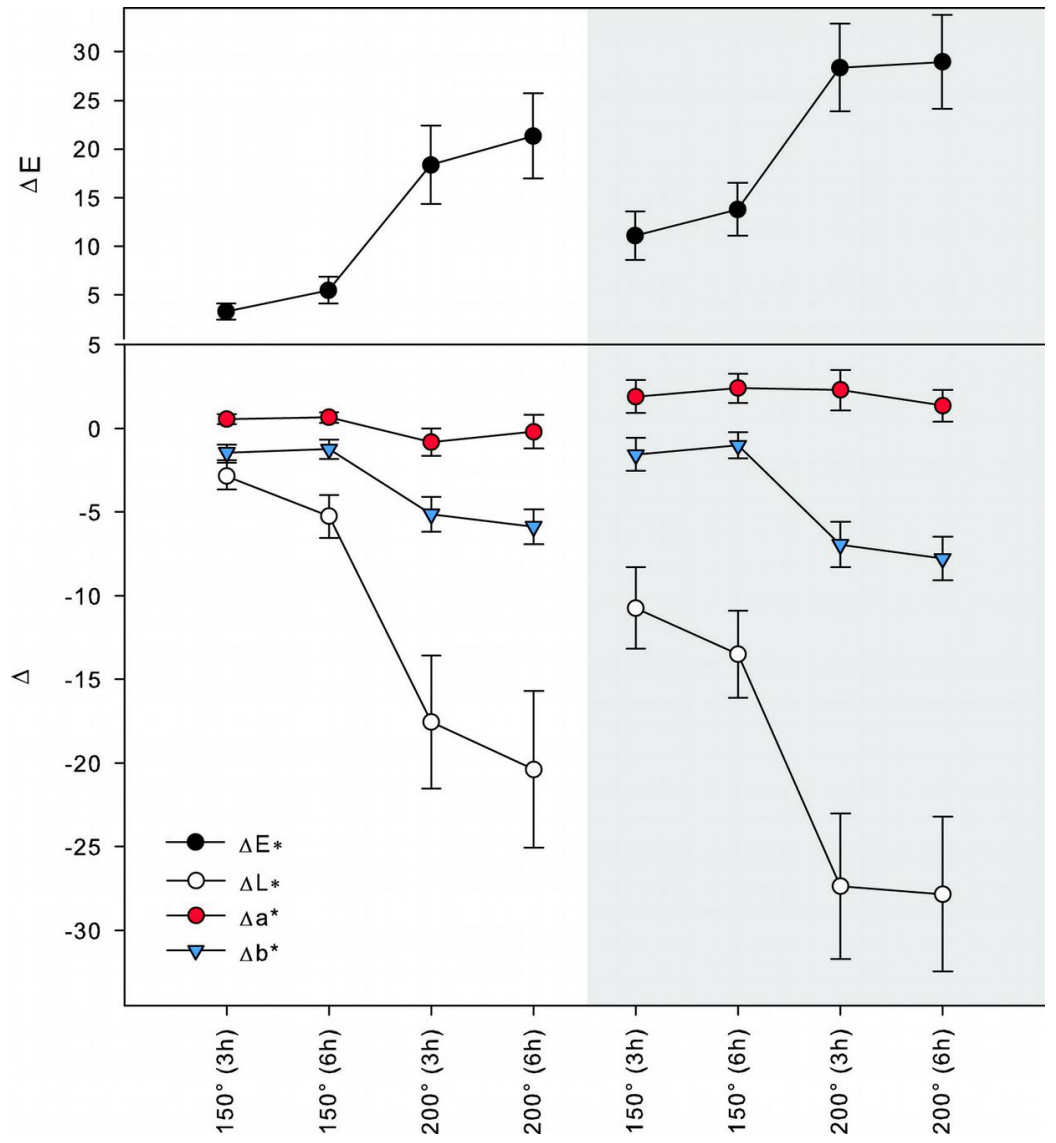

Fig. 6 - Influence of treatments on the average color parameters. The shaded area refers to samples submitted to the steaming treatment.

Tab. 5 - The color coordinate differences between sapwood and heartwood. (ST): steaming.

\begin{tabular}{clccc}
\hline Group & $\begin{array}{l}\text { Treatment } \\
\left({ }^{\circ} \mathbf{C}, \mathbf{h}\right)\end{array}$ & $\begin{array}{c}\text { Lightness } \\
\left(\boldsymbol{L}^{*}\right)\end{array}$ & $\begin{array}{c}\text { Green-red } \\
\text { axis }\left(\boldsymbol{a}^{*}\right)\end{array}$ & $\begin{array}{c}\text { Blue-yellow } \\
\text { axis }\left(\boldsymbol{b}^{*}\right)\end{array}$ \\
\hline 1 & Control & -13.4 & 2.7 & -9.5 \\
2 & $150 \times 3 \mathrm{~h}$ & -5.1 & -0.7 & -8.1 \\
3 & $150 \times 6 \mathrm{~h}$ & -10.3 & -11.2 & -13.9 \\
4 & $200 \times 3 \mathrm{~h}$ & -9.8 & -3.8 & -18.2 \\
5 & $200 \times 6 \mathrm{~h}$ & -8.6 & -5.9 & -24.8 \\
6 & $\mathrm{ST}+150 \times 3 \mathrm{~h}$ & -12.6 & -7.9 & -21.2 \\
7 & $\mathrm{ST}+150 \times 6 \mathrm{~h}$ & -7.8 & -10.5 & -12.1 \\
8 & $\mathrm{ST}+200 \times 3 \mathrm{~h}$ & -10.8 & -14.3 & -21.9 \\
9 & ST $+200 \times 6 \mathrm{~h}$ & -5.0 & -8.4 & -12.0 \\
\hline
\end{tabular}

Tab. 6 - Average lignin content in the wood (ALW), sapwood, and heartwood. Sapwood and heartwood variation (\%) are compared with the control. (SD): Standard deviation; (ST): steaming.

\begin{tabular}{clcccccc}
\hline Group & $\begin{array}{l}\text { Treatment } \\
\left({ }^{\circ} \mathbf{C}, \mathbf{h}\right)\end{array}$ & $\begin{array}{c}\text { ALW } \\
(\mathbf{\%})\end{array}$ & SD & $\begin{array}{c}\text { Sapwood } \\
\mathbf{( \% )}\end{array}$ & $\begin{array}{c}\text { Sapwood } \\
\text { variation } \\
(\%)\end{array}$ & $\begin{array}{c}\text { Heartwood } \\
(\%)\end{array}$ & $\begin{array}{c}\text { Heartwood } \\
\text { variation } \\
(\%)\end{array}$ \\
\hline 1 & Control & 26.5 & 2.7 & 24.6 & 0 & 28.4 & 0 \\
2 & $150 \times 3 \mathrm{~h}$ & 27.5 & 1.6 & 26.4 & 7.3 & 28.7 & 0.7 \\
3 & $150 \times 6 \mathrm{~h}$ & 25.8 & 0.7 & 25.3 & 2.8 & 26.3 & -7.4 \\
4 & $200 \times 3 \mathrm{~h}$ & 27.2 & 0.8 & 27.8 & 8.1 & 28.6 & -2.6 \\
5 & $200 \times 6 \mathrm{~h}$ & 28.2 & 0.5 & 26.6 & 13.0 & 27.7 & 0.5 \\
6 & $\mathrm{ST}+150 \times 3 \mathrm{~h}$ & 25.6 & 0.1 & 25.6 & 3.8 & 25.7 & -9.6 \\
7 & $\mathrm{ST}+150 \times 6 \mathrm{~h}$ & 25.1 & 0.7 & 25.6 & 4.0 & 24.6 & -13.3 \\
8 & $\mathrm{ST}+200 \times 3 \mathrm{~h}$ & 26.5 & 1.8 & 25.2 & 2.4 & 27.7 & -2.6 \\
9 & $\mathrm{ST}+200 \times 6 \mathrm{~h}$ & 28.0 & 0.9 & 27.3 & 10.9 & 28.6 & 0.5 \\
\hline
\end{tabular}

pared with the control, but not in the heartwood samples, indicating the importance of steaming when wet wood is used. In a recent study, Todaro et al. (2013) found contrasting results for Turkey oak wood, showing that an increase of lignin content in the heartwood after a high temperature treatment was associated with a previous steaming treatment on wet wood. However, Dashti et al. (2012) highlighted the difference of lignin content between sapwood and heartwood in terms of their different permeability and diffusion coefficients in Quercus infectoria Olivier. The authors stated that the presence of tylosis in the heartwood, which lowers the diffusion rate of water vapor through wood, has a significant effect on the final impact of steaming treatment on the lignin content. In our study, the low presence of water during steaming and consequently the reduced destruction of the cellular wall structure caused a slower degradation of the heartwood compounds and reduced the lignin content. Funaoka et al. (1990) also suggested that the water contained in the wood enhances the condensation of lignin.

\section{Conclusions}

The results of this study confirmed that hydrothermal treatments reduce the hygroscopic and dimensional variations of pubescent oak wood, which is currently underused due to its poor dimensional stability. Steaming and heating temperature were found to significantly affect water adsorption, strength, darkening, and lignin content after treatment. Interesting results about moisture content and relative swelling were found by applying the combined treatment of steaming and heating at $200{ }^{\circ} \mathrm{C}$, while the treatments at $150{ }^{\circ} \mathrm{C}$ gave poorer results regardless of steaming. Furthermore, the combined effect of steaming and heating caused an increase in the axial compression strength.

Considering that pubescent oak has a highdensity wood characterized by wide rays and internal stresses, the usage of high temperatures could determine undesired collapses. Hydrothermal treatments led to significant modifications of the wood color. The great color difference between the sapwood and heartwood of pubescent oak could be weakened by steaming. Concerning the lignin content, a similar trend was found for sapwood and heartwood. Moreover, more lignin was detected in samples subjected to high temperature treatments, while its content in sapwood was higher than in heartwood.

Since pubescent oak is widespread in several Mediterranean countries, the improvement of the technological properties of its wood may be of high interest, possibly reducing the amount of imported timber with positive economic effects. Though the availability of high-quality forest stands of this species is currently limited, it could be ad- 
visable the use of this wood to replace other oak species used in product manufacturing.

The present work has focused on several parameters of pubescent oak wood that could be interesting for industry. However, due to the relatively small sample size adopted, further investigations are needed to confirm the modifications and technological improvements observed in this study.

\section{Acknowledgments}

We thank Giuseppe Maltempo and Pasquale Di Chicco, undergraduate students of the University of Basilicata, for providing assistance during the laboratory measurements.

\section{References}

Assor C, Placet V, Chabbert B, Habrant A, Lapierre C, Pollet B, Perre P (2009). Concomitant changes in viscoelastic properties and amorphous polymers during the hydrothermal treatment of hardwood and softwood. Journal of Agricultural and Food Chemistry 57: 6830-6837. - doi: 10.1021/jf901373s

Babicki R, Grzeczynski T, Wroblewska H (1977). Effect of hydro-thermal-treatment of green beech wood on its chemical and physico-mechanical properties. Wood Science and Technology 11: 125-131. [online] URL: http://link.springer.com/ article/10.1007/BF00350990

Bamber RK, Fukazawa K (1985). Sapwood and heartwood: a review. Forest Products Abstract 8: 265-276

Boonstra MJ, Van Acker J, Tjeerdsma BF, Kegel EV (2007). Strength properties of thermally modified softwoods and its relation to polymeric structural wood constituents. Annals of Forest Science 64: 679-690. - doi: 10.1051/forest:2007 048

Burgert I, Bernasconi A, Niklas K, Eckstein D (2001). The influence of rays on the transverse elastic anisotropy in green wood of deciduous trees. Holzforschung 55: 449-454. - doi: 10.1515 /HF.2001.074

Dashti H, Shahverdi M, Reza Taghiyari H, Salehpur S, Heshmati S (2012). Effects of steaming and microwave pretreatments on mass transfer characteristics of Aleppe oak (Quercus infectoria). BioResources 7 (3): 3262-3273. - doi: 10.1 5376/biores.7.2.1907-1918

Esteves BM, Pereira HM (2009). Heat treatment of wood. BioResources 4 (1): 370-404.

Funaoka M, Kako T, Abe I (1990). Condensation of lignin during heating of wood. Wood Science and Technology 24: 277-288. - doi: 10.1007/ BF01153560

Giordano G (1981). Tecnologia del legno [Wood technology]. UTET, Torino, Italy, pp. 1136. [in Italian]

Giordano G (1994). Caratteristiche e lavorazioni fondamentali [Characteristics and main processes]. In: "Il legno, vol 2" (Consorzio LL ed). Reggio Emilia, Italy, pp. 1136. [in Italian]

Hill CAS (2006). Wood modification: chemical, thermal and other processes. John Wiley \& Sons Ltd, Chichester, UK. pp. 239. - doi: 10.1002/047
0021748

Hillis WE (1987). Heartwood and tree exudates. Springer-Verlag, New York, USA, pp. 268. [online] URL: http://www.cabdirect.org/abstracts/ 19880621775.html

IGN (2013). Résultats d'inventaire forestier - résultats standards (campagnes 2008 à 2012) [Results of forest inventory - standard results (campaigns from 2008 to 2012)]. Tome national version régions administratives. Service de l'inventaire forestier et statistique, Institut National de l'Information Géographique et Forestière (IGN), Sante Mandé, Paris, France. [in French]

INFC (2007). Le stime di superficie 2005. Inventario Nazionale delle Foreste e dei Serbatoi Forestali di Carbonio [Estimating forest area 2005. First part]. In: "Inventario Nazionale delle Foreste e dei Serbatoi Forestali di Carbonio" (Tabacchi G, De Natale F, Di Cosmo L, Floris A, Gagliano C, Gasparini P, Genchi L, Scrinzi G, Tosi V eds). MiPAF, Corpo Forestale dello Stato, Ispettorato Generale, CRA-ISAFA, Trento, Italy, pp. 409. [online] URL: http://www.infc.it

Jalas J, Suominen J (1976). Atlas Florae Europaeae: distribution of vascular plants in Europe (vol 3). Salicaceae to Balanophoraceae. The Committee for Mapping the Flora of Europe \& Societas Biologica Fennica Vanamo, Helsinki, Finland, pp. 128. [ISBN 951-9108-02-5]

Kartal SN, Unsal O, Yilgor N (2001). Physical, mechanical, and chemical properties of steamed beech wood. (Fundamental Disciplines). Forest Products Journal 51 (11-12): 89-93. [online] URL: http://cat.inist.fr/?aModele=afficheN\&cpsidt $=13397390$

Kollman F (1936). Technologie des Holzes und der Holzwerkstoffe [Wood technology and wood-based materials]. Springer Verlag, Berlin, Germany, pp. 346. [in German]

Kollman F, Schneider A (1963). Über das Sorptionsverhalten wärmebehandelter Hölzer [About the sorption behavior of heat-treated wood]. Holz als Roh- und Werkstoff 21: 77-85. [in German] doi: 10.1007/BF02609705

Mitchell PH (1988). Irreversible property changes of small loblolly pine specimens heated in air, nitrogen or oxygen. Wood and Fiber Science 20 (3): 320-355. [online] URL: http://swst.metapress.com/content/y064k013g2451273/

Pallardy SG (2008). Physiology of woody plants. Academic Press, S. Diego, CA, USA, pp. 464. [online] URL: http://books.google.com/books? id=lErfWWicYb4C

Reiterer A, Burgert I, Sinn G, Tschegg S (2002). The radial reinforcement of the wood structure and its implication on mechanical and fracture mechanical properties. A comparison between two tree species. Journal of materials science 37 : 935-940. - doi: 10.1023/A:1014339612423

Rybarczyk W, Ganowicz R (1974). A theoretical description of the swelling pressure of wood. Wood Science and Technology 8: 233-241. - doi: 10.1007/BF00352027

Schmidt A (1986). Untersuchungen Über die Ursachen der Verfärbungen von Eichenholz bei der technischen Trocknung [Studies on the discolo- ration causes of dried oak wood]. Holzforsch Holzverwert 38: 25-36. [in German]

Schwarz O (1993). Quercus L. In: "Flora Europaea" (Tutin TG, Burges NA, Chater AO, Edmondson JR, Heywood VH, Moore DM, Valentine DH, Walters SM, Webb DA eds). Cambridge University Press, Cambridge, UK, pp. 7276.

Sohar K, Vitasb A, Läänelaida A (2012). Sapwood estimates of pedunculate oak (Quercus robur L.) in eastern Baltic. Dendrochronologia 30: 49-56. - doi: 10.1016/j.dendro.2011.08.001 Stamm AJ (1956). Thermal degradation of wood and cellulose. Industrial and Engineering Chemistry 48(3): 413-417. - doi: 10.1021/ie51398a022 Stamm AJ, Burr H, Kline A (1946). Staybwood heat stabilized wood. Industrial and Engineering Chemistry 38 (6): 630-634. - doi: 10.1021/ie50 $438 \mathrm{a} 027$

Sundqvist B (2004). Colour changes and acid formation in wood during heating. $\mathrm{PhD}$ thesis, $\mathrm{Lu}-$ leå University of Technology, Skellefteå, Sweden, pp. 115.

Sundqvist B, Morén T (2002). The influence of wood polymers and extractives on wood colour induced by hydrothermal treatment. Holz als Roh- und Werkstoff 60: 375-376. - doi: 10.1007/ s00107-002-0320-2

Taylor AM, Gartner BL, Morrel JJ (2002). Heartwood formation and natural durability - a review. Wood and fiber science 34 (4): 587-611. [online] URL: http://swst.metapress.com/content/157542 2520216677/

TAPPI (1954). Official Standard, T13-m54. Technical Association of Pulp and Paper Industry, New York, USA

Terziev N (1995). Migration of low-molecular sugars and nitrogenous compounds in Pinus sylvestris $\mathrm{L}$. during kiln and air drying. Holzforschung 49: 565-574. - doi: 10.1515/hfsg. 1995. 49.6.565

Tjeerdsma BF, Militz H (2005). Chemical changes in hydrothermal treated wood: FTIR analysis of combined hydrothermal and dry heat-treated wood. European Journal of Wood and Wood Products 63 (2): 102-111. - doi: 10.1007/s0010 7-004-0532-8

Todaro L (2012). Effect of steaming treatment on resistance to footprints in Turkey oak wood for flooring. European Journal of Wood and Wood Products 70 (1-3): 209-214. - doi: 10.1007/s001 07-011-0542-2

Todaro L, Zuccaro L, Marra M, Basso B, Scopa A (2012a). Steaming effects on selected wood properties of turkey oak by spectral analysis. Wood Science and Technology 46 (1-3): 89-100. - doi: 10.1007/s00226-010-0377-8

Todaro L, Zanuttini R, Scopa A, Moretti N (2012b). Influence of combined hydrothermal treatments on selected properties of Turkey oak (Quercus cerris L.) wood. Wood Science and Technology 46 (1-3): 563-578. - doi: 10.1007/ s00226-011-0430-2

Todaro L, Dichicco P, Moretti N, Auria M (2013). Effect of combined steam and heat treatments on extractives and lignin in sapwood and heartwood 
of Turkey oak (Quercus cerris L.) wood. BioResources 8 (2): 1718-1730. - doi: 10.15376/bio res.8.2.1718-1730

Tolvaj L, Molnar S (2006). Colour homogenisation of hardwood species by steaming. Acta Silvatica \& Lignaria Hungarica 2: 105-112. [online] URL: http://nogt.ktk.nyme.hu/fileadmin/ dokumentumok/fmk/acta_silvatica/cikkek/Vol02 -2006/tolvaj molnar.pdf

UNI-ISO-3130 (1985). Legno. Determinazione dell'umidità per le prove fisiche e meccaniche [Wood. Determination of moisture content for physical and mechanical tests]. Ente Nazionale Italiano di Unificazione, Milan, Italy, pp. 2. [in Italian]
UNI-ISO-3131 (1985). Legno. Determinazione della massa volumica per le prove fisiche e meccaniche [Wood. Determination of density for physical and mechanical tests]. Ente Nazionale Italiano di Unificazione, Milan, Italy, pp. 4. [in Italian]

UNI-ISO-3787 (1985). Legno. Metodi di prova. Determinazione della resistenza a compressione parallela alla fibratura [Wood. Determination of ultimate stress in compression parallel to grain]. Ente Nazionale Italiano di Unificazione, Milan, Italy, pp. 4. [in Italian]

UNI-ISO-4859 (1988). Legno. Determinazione del rigonfiamento radiale e tangenziale [Wood. Determination of radial and tangential swelling].
Ente Nazionale Italiano di Unificazione, Milan, Italy, pp. 4. [in Italian]

UNI-ISO-4860 (1988). Legno. Determinazione del rigonfiamento volumetrico [Wood. Determination of total swelling]. Ente Nazionale Italiano di Unificazione, Milan, Italy, pp. 6. [in Italian]

Yildiz S, Gezer ED, Yildiz ÜC (2006). Mechanical and chemical behaviour of spruce wood modified by heat. Build Environmental 41(12): 1762-1766. - doi: 10.1016/j.buildenv.2005.07.0 17

Zaman A, Alen R, Kotilainen R (2000). Thermal behavior of Pinus sylvestris and Betula pendula at 200-230 ${ }^{\circ} \mathrm{C}$. Wood and Fiber Science 32 (2): 138-143. 